\title{
Expression of urokinase-type plasminogen activator and its receptor in squamous cell carcinoma of the oral tongue
}

Marianna Sampaio SERPA(a)

Rodrigo Porpino MAFRA(a)

Salomão Israel Monteiro Lourenço QUEIROZ(a)

Leorik Pereira da SILVA ${ }^{(a)}$

Lélia Batista de SOUZA ${ }^{(a)}$

Leão Pereira PINTO(a)

(a) Universidade Federal do Rio Grande do Norte - UFRN, Department of Dentistry, Postgraduate Program in Oral Pathology, Natal, RN, Brazil.
Declaration of Interest: The authors certify that they have no commercial or associative interest that represents a conflict of interest in connection with the manuscript.

\section{Corresponding Author:}

Marianna Sampaio Serpa

E-mail: mariannaserpa@hotmail.com

htrps://doi.org/10.1590/1807-3107bor-2018.vol32.0093

Submitted: February 17, 2018

Accepted for publication: June 27, 2018

Last revision: July 25, 2018
Abstract: Urokinase-type plasminogen activator (uPA) and its receptor (uPAR) act in the proteolysis of basement membrane and extracellular matrix structures, facilitating tumor invasion. The purpose of this study was to evaluate the relationship between these proteins and clinicopathological parameters in squamous cell carcinoma of the oral tongue (SCCOT). Sixty cases of SCCOT were submitted to immunohistochemistry and analyzed semiquantitatively at the invasion front and in the tumor core. The results were associated with lymph node metastasis, clinical stage, locoregional recurrence, clinical outcome and histological grade of malignancy. A higher expression of uPA was observed in cases of tumors of high-grade versus low-grade malignancy $(p=0.010)$. Moreover, the cases with the worst pattern of invasion presented an overexpression of $\mathrm{uPA}(\mathrm{p}=0.011)$. The presence of locoregional recurrence was associated with uPAR $(p=0.039)$, and the expression of both biomarkers was much higher at the invasion front than in the tumor core $(\mathrm{p}<0.001)$. The results suggest $\mathrm{uPA}$ and UPAR are involved in the progression and aggressiveness of SCCOT, mainly at the tumor-host interface.

Keywords: Carcinoma, Squamous Cell; Immunohistochemistry; Plasminogen Activator.

\section{Introduction}

The plasminogen activator system (PAS) is responsible for the conversion of the pro-enzyme plasminogen into serine protease plasmin. Plasmin not only plays a role in the fibrinolysis of blood clots and the restoration of blood flow, but also acts pathophysiologically in several other processes, such as cell migration, angiogenesis, tissue remodeling and tumor cell invasion. ${ }^{1,2}$

In carcinogenesis, plasmin directly degrades components of the basement membrane and interstitial extracellular matrix, such as laminin, collagen IV and fibronectin, or indirectly degrades them by the activation of other proteinases like matrix metalloproteinases (MMP)., Moreover, plasmin can activate fibroblast growth factor (FGF), vascular endothelial growth factor (VEGF), and transforming growth factor- $\beta$ (TGF- $\beta$ ), which all favor tumor growth and invasion. ${ }^{3,5}$ 
Two types of PAS activators are responsible for the formation of plasmin: tissue-type plasminogen activator (tPA) and urokinase-type plasminogen activator (uPA). tPA acts exclusively on fibrinolysis and uPA binds to its specific receptor, the urokinase-type plasminogen activator receptor (uPAR), to promote tissue repair. ${ }^{4,6}$ Increased expression of uPA/uPAR has been observed in some tumors, including those in stomach, ${ }^{7}$ colorectal $^{8}$ and oral cavity. ${ }^{9,10,11}$

Oral squamous cell carcinoma (OSCC) is a common tumor with a 5-year survival rate that ranges from $15-50 \% .12,13$ The oral tongue (SCCOT) is the most common site, representing $25-40 \%$ of the cases. ${ }^{14}$ This anatomic location has an enhanced risk of recurrence and lymph node metastasis due to its rich lymphatic network and extensive muscular area. ${ }^{14,15}$ The high incidence and aggressive behavior of SCCOT has warranted a special study of this lesion separately from those of other oral locations.

The objective of this study was to evaluate the immunoexpression of UPA and UPAR in SCCOT, and associate these results with clinicopathological parameters. Our aim was to gain a better understanding of the role of these proteins, and thus improve our comprehension of the biological behavior of this malignant neoplasm.

\section{Methodology}

\section{Samples}

All the cases of SCCOT registered at the Anatomic Pathology Service of the Dr. Luiz Antônio Hospital, Natal-RN, from 2002-2010, were evaluated. Only primary tumors treated by surgical excision without radiotherapy or previous chemotherapy were selected. Anatomopathological reports had to be made out for cases with regional lymph node metastasis. After a thorough analysis, 60 cases were included in the study.

Clinical information, such as age, gender, TNM clinical stage, presence/absence of regional lymph node metastasis, presence/absence of locoregional recurrence, and clinical outcome were obtained from the pertinent medical records. This study was approved by the Research Ethics Committee of Liga Norte-Riograndense Contra o Câncer (LNRCC) ( ${ }^{\circ}$ 1.170.634), and complies with the Helsinki Declaration.

\section{Morphological analysis}

All the cases were cut into $5-\mu \mathrm{m}$-thick histological sections and stained by hematoxylin-eosin (HE). Two blinded trained examiners determined the histological grade of malignancy at the invasion front, based on Bryne's grading system. ${ }^{16}$ The cases were classified as having a low- or high-grade of malignancy, according to the adaptation developed by Silveira et al. ${ }^{17}$ In discordant cases, the evaluators reexamined the slides together to obtain a consensual result.

\section{Immunohistochemical reactions}

The specimens were cut into $3-\mu \mathrm{m}$-thick sections and placed on histological slides prepared with an organosilane-based adhesive. The sections were deparaffinized, rehydrated and immersed in 3\% hydrogen peroxide. The anti-uPA (H-140, polyclonal, Santa Cruz Biotechnology, Dallas, USA) and anti-uPAR (E-3, monoclonal, Santa Cruz Biotechnology, Dallas, USA) antibodies were diluted in 1:500 and incubated at $4^{\circ} \mathrm{C}$ overnight. The amplification reaction was performed using the HiDef Detection HRP-Polymer System (954D; Sigma-Aldrich Co, Darmstadt, Germany) and visualized by 3,3-diaminobenzidine (Liquid DAB + Substrate, Dako North America Inc., Carpinteria, USA). Counterstaining was performed with Harris hematoxylin, and the slides were mounted in Permount ${ }^{\circledR}$ resin. Tumor tissues of OSCC that revealed high immunoexpression were the positive controls, whereas primary antibodies were replaced by $1 \%$ bovine serum albumin (BSA) in buffer solution for negative control.

\section{Immunohistochemical analysis}

A blinded trained examiner evaluated all the cases at two distinct moments. A semiquantitative analysis of $\mathrm{UPA}$ and $\mathrm{UPAR}$ was conducted along the invasion front and the tumor core, under 40X magnification (Olympus CX31, Tokyo, Japan). An adaptation of the methodology established by Magnussen et al. ${ }^{11}$ was undertaken for both biomarkers, based on the proportion of positive tumor cells, as follows: $0=$ none; $1=1-10 \% ; 2=11-50 \%$; and $3=>50 \%$. Tumor cells considered positive presented a brownish color of the membrane and/or the cytoplasm. 


\section{Statistical analysis}

The results were analyzed using the Statistical Package for the Social Sciences software (version 17.0; SPSS Inc., Chicago, USA). The non-parametric Mann-Whitney test analyzed the differences between uPA and UPAR and the clinicopathological variables. The expression of the markers in relation to the morphological parameters proposed by Bryne ${ }^{16}$ was evaluated using the Kruskal-Wallis test. Statistical differences between the markers on the deep invasive front and in the tumor core were obtained using the Wilcoxon test. A significance level of 5\% ( $p<$ $0.05)$ was established for all the statistical tests. The kappa test evaluated the interexaminer concordance according to Bryne's grading system $(\mathrm{k}=0.443 ; \mathrm{p}<$ $0.001)$, as well as the intraexaminer agreement for each immunohistochemical analysis regarding the invasion front and tumor core of $\mathrm{UPA}(\mathrm{k}=0.675$ and 0.727 , respectively; $\mathrm{p}<0.001)$ and uPAR $(\mathrm{k}=0.680$ and 0.528 , respectively; $\mathrm{p}<0.001$ ).

\section{Results}

\section{Clinicopathological results}

Of the 60 cases of SCCOT included in this study, $31(51.7 \%)$ had lymph node metastasis, and the remaining $29(48.3 \%)$ had no such metastasis. Males predominated $(n=41 ; 68.3 \%)$ and the mean age was 63.1 years. Clinical staging was categorized into two groups, with a preponderance of stages III and IV ( $\mathrm{n}=$ $38 ; 63.3 \%)$ in relation to stages I and II ( $\mathrm{n}=22 ; 36.7 \%)$.
Only cases with a 5-year follow-up were considered for analysis of recurrence and outcome, yielding 46 cases. Of these, 14 (30.4\%) presented recurrence. Regarding the clinical outcome, only cases of death and remission of the disease were considered. Three cases were excluded on the grounds of disease in progress. Of the 43 remaining cases, the most prevalent outcome was death $(n=24$; $55.8 \%$ ) in relation to remission $(n=19 ; 44.2 \%)$.

The majority of the SCCOT cases were classified as tumors of high-grade malignancy ( $\mathrm{n}=48 ; 80 \%$ ) in relation to low-grade malignancy ( $\mathrm{n}=12 ; 20 \%)$. Most cases were highly keratinized ( $\mathrm{n}=25 ; 41.7 \%$ ), with moderate nuclear pleomorphism $(n=29 ; 48.3 \%)$, cellular dissociation $(n<15)(n=42 ; 70 \%)$ and moderate inflammatory infiltrate $(\mathrm{n}=35 ; 58.3 \%)$.

\section{Immunohistochemical results}

Immunohistochemical expression of uPA was observed in the neoplastic cells of 55 cases (91.7\%) at the invasion front, and in 39 cases (65\%) in the tumor core (Figure 1). Most of the cases at the tumor-host interface were classified as score $1(n=23 ; 38.3 \%)$, and only 5 cases had no staining. On the other hand, most of the cases in the tumor core were score $0(n=21 ; 35 \%)$. The Wilcoxon test revealed a higher expression of $\mathrm{UPA}$ at the invasion front in relation to the tumor core $(p<0.001)$ (Table 1$)$.

The clinical parameters showed no significant differences for uPA expression (Table 2). Concerning the histological grade, most high-grade tumors had a score 2 at the deep invasive front $(\mathrm{n}=17 ; 35.4 \%)$, whereas low-grade tumors were mostly score $1(\mathrm{n}=8$;
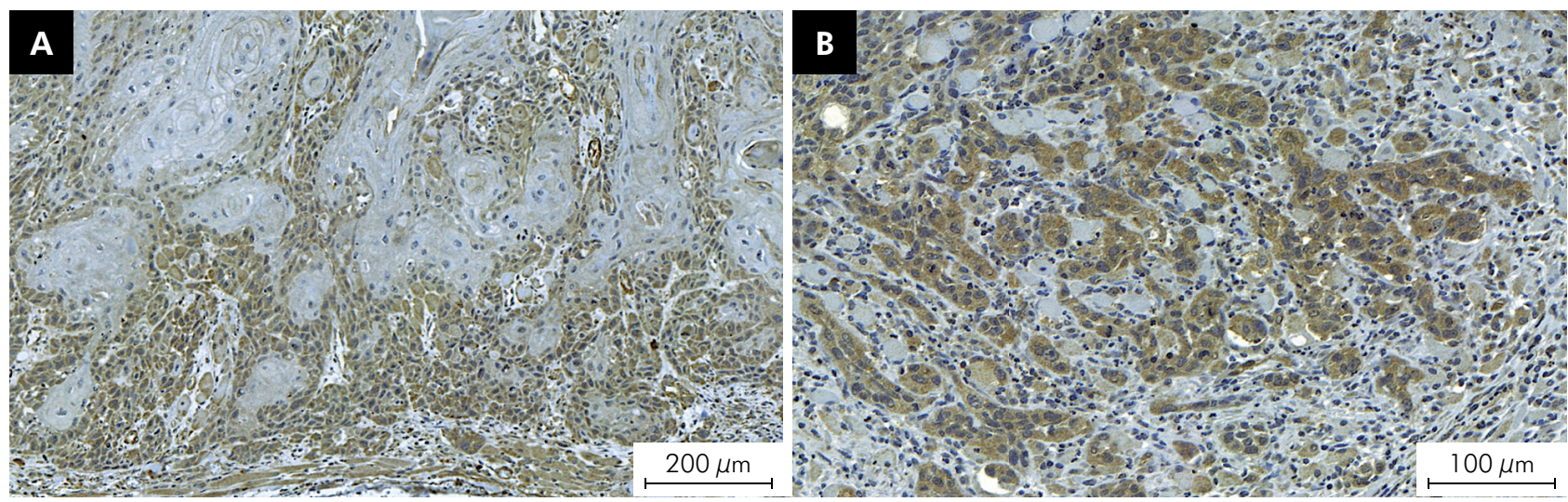

Figure 1. Immunohistochemical expression of UPA in SCCOT. (a) Low magnification showing the immunostaining at the invasion front and in the tumor core. (b) High magnification showing the immunostaining at the invasion front. 
Table 1. Immunohistochemical scores of UPA according to the tumor area.

\begin{tabular}{lccccc}
\hline \multirow{2}{*}{ Tumor area } & \multicolumn{4}{c}{ Immunohistochemical score [n (\%)] } & \multirow{2}{*}{$\mathrm{p}$} \\
\cline { 2 - 5 } & 0 & 1 & 2 & 3 & \\
\hline Invasion front & 5 & 23 & 18 & 14 & \\
& $(8.3 \%)$ & $(38.3 \%)$ & $(30 \%)$ & $(23.3 \%)$ & $<.001^{*}$ \\
Tumor core & 21 & 20 & 10 & 9 & \\
& $(35 \%)$ & $(33.3 \%)$ & $(16.7 \%)$ & $(15 \%)$ & \\
\hline
\end{tabular}

*Statistically significant.

Table 2. Immunopositivity of UPA at the invasion front and in the tumor core according to clinicopathological parameters.

\begin{tabular}{|c|c|c|c|c|c|}
\hline $\begin{array}{l}\text { Location/ } \\
\text { Parameters }\end{array}$ & Group & $\mathrm{n}$ & Median & $Q_{25}-Q_{75}$ & $p$ \\
\hline \multicolumn{6}{|c|}{ Invasion front } \\
\hline \multirow{2}{*}{$\begin{array}{l}\text { Nodal } \\
\text { metastasis }\end{array}$} & Absent & 29 & 1.00 & $1.00-2.50$ & 0.907 \\
\hline & Present & 31 & 2.00 & .00 & \\
\hline \multirow{2}{*}{$\begin{array}{l}\text { Clinical } \\
\text { stage }\end{array}$} & $|-| \mid$ & 22 & & $1.00-2.75$ & 0.846 \\
\hline & III-IV & 38 & 2 & .00 & \\
\hline \multirow{2}{*}{ Recurrence } & Abser & 32 & & & 0.564 \\
\hline & Pres & 14 & 2.00 & 00 & \\
\hline \multirow{2}{*}{ Outcome } & Rem & 19 & & 00 & 0.888 \\
\hline & Dea & 24 & 2.00 & 1.0 & \\
\hline \multirow{3}{*}{$\begin{array}{l}\text { Histological } \\
\text { grade }\end{array}$} & Low-grade & 12 & 1.00 & 1.0 & $0.010^{*}$ \\
\hline & High-g & 48 & 2.00 & $1.00-3.00$ & \\
\hline & Banc & 9 & 1.00 & 00 & 0.01 \\
\hline \multirow{2}{*}{$\begin{array}{l}\text { Invasion } \\
\text { pattern }\end{array}$} & $\begin{array}{l}\text { Small groups } \\
(n>15)\end{array}$ & 9 & 1.00 & 0.50 & \\
\hline & $\begin{array}{l}\text { Cellular dissociation } \\
(\mathrm{n}<15)\end{array}$ & 42 & 2.00 & 1.0 & \\
\hline \multicolumn{6}{|c|}{ Tumor core } \\
\hline \multirow{2}{*}{$\begin{array}{l}\text { Nodal } \\
\text { metastasis }\end{array}$} & Abse & 29 & 1.00 & 2.00 & 0.572 \\
\hline & Pres & 31 & & 0.0 & \\
\hline \multirow{2}{*}{$\begin{array}{l}\text { Clinical } \\
\text { stage }\end{array}$} & $|-| \mid$ & 22 & 1.00 & $0.00-2.00$ & 0.942 \\
\hline & III-IV & 38 & 1.00 & & \\
\hline \multirow{2}{*}{ Recurrence } & Abser & 32 & 1.00 & $0.00-2.00$ & 0.252 \\
\hline & Present & 14 & 1.00 & $0.00-1.25$ & \\
\hline \multirow{2}{*}{ Outcome } & Remission & 19 & 1.00 & $0.00-2.00$ & 1.000 \\
\hline & Death & 24 & 1.00 & $0.00-2.00$ & \\
\hline
\end{tabular}

*Statistically significant.
66.7\%). The Mann-Whitney test revealed higher uPA expression in cases of high-grade compared to lowgrade malignancy $(p=0.010)$ (Table 2$)$. When the morphological parameters were evaluated, a higher uPA expression was observed in the pattern of cellular dissociation invasion $(n<15)$, in relation to the pattern of bands and/or strands and small groups $(n>15)$ $(p=0.011)($ Table 2$)$.

uPAR expression was observed in the epithelial cells of 46 cases $(76.7 \%)$ at the invasion front, and in 29 cases (48.4\%) in the tumor core (Figure 2). Most cases at the invasion front were classified as score 1 $(46.7 \%)$, whereas most cases in the tumor core presented a score of $0(51.7 \%)$. The Wilcoxon test revealed a significantly higher $(\mathrm{p}<0.001)$ expression of uPAR at the invasion front than in the tumor core (Table 3).

Regarding the clinical parameters, most cases at the invasion front with no locoregional recurrence presented a score of $1(n=16 ; 50 \%)$ and $0(n=10 ; 31.3 \%)$, whereas the cases with recurrence showed a predominance of score $1(n=5 ; 35.7 \%)$ and $2(n=4 ; 28.6 \%)$. The MannWhitney test revealed a higher UPAR expression at the invasion front in the cases with recurrence versus without recurrence $(p=0.039)$ (Table 4$)$. No statistically significant differences were observed for the other clinical parameters or the histological grade (Table 4).

\section{Discussion}

uPA and UPAR are implicated in tumorigenesis, since they are responsible for greater infiltration
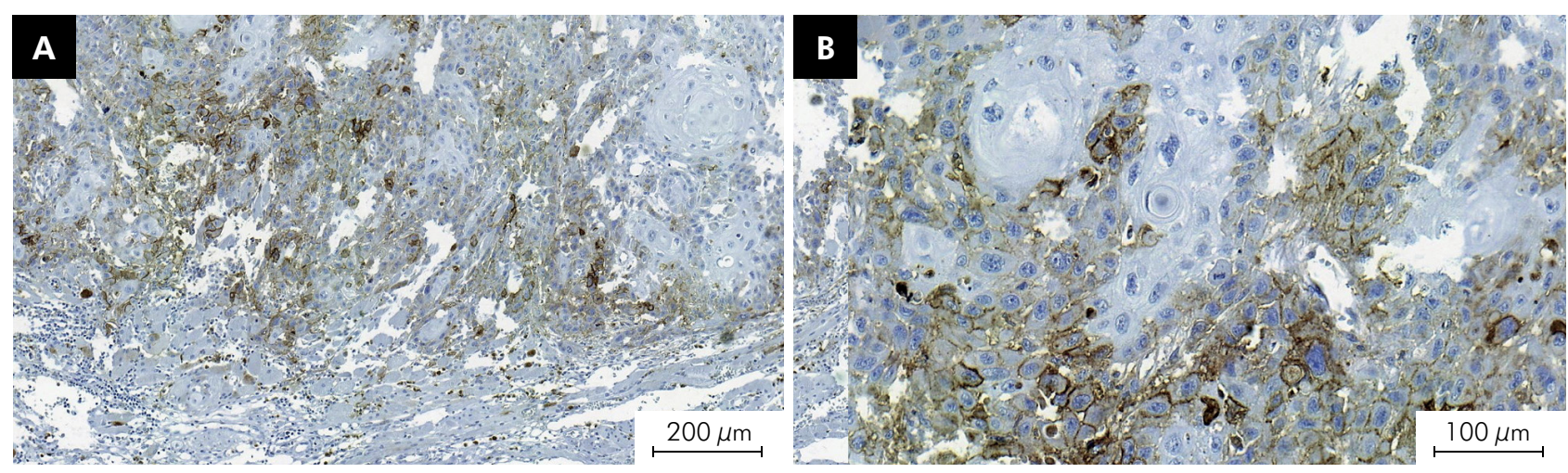

Figure 2. Immunohistochemical expression of uPAR in SCCOT. (a) Low magnification showing the immunostaining at the invasion front and in the tumor core. (b) High magnification showing the immunostaining at the invasion front. 
Table 3. Immunohistochemical scores of UPAR according to the tumor area.

\begin{tabular}{lccccc}
\hline \multirow{2}{*}{ Tumor area } & \multicolumn{4}{c}{ Immunohistochemical score [n (\%)] } & \\
\cline { 2 - 5 } & 0 & 1 & 2 & 3 & \\
\hline \multirow{2}{*}{ Invasion front } & 14 & 28 & 10 & 8 & $(13.3 \%)<0.001^{*}$ \\
& $(23.3 \%)$ & $(46.7 \%)$ & $(16.7 \%)$ & \\
Tumor core & 31 & 25 & 4 & 0 \\
& $(51.7 \%)$ & $(41.7 \%)$ & $(6.6 \%)$ & $(0 \%)$ \\
\hline
\end{tabular}

*Statistically significant.

Table 4. Immunopositivity of UPAR at the invasion front and in the tumor core according to the clinicopathological parameters.

\begin{tabular}{|c|c|c|c|c|c|}
\hline $\begin{array}{l}\text { Location/ } \\
\text { Parameters }\end{array}$ & Group & $n$ & Median & $Q_{25}-Q_{75}$ & $\mathrm{p}$ \\
\hline \multicolumn{6}{|c|}{ Invasion front } \\
\hline \multirow{2}{*}{$\begin{array}{l}\text { Nodal } \\
\text { metastasis }\end{array}$} & Absent & 29 & 1.00 & $1.00-2.00$ & 0.196 \\
\hline & Present & 31 & 1.00 & $0.00-1.00$ & \\
\hline \multirow{2}{*}{$\begin{array}{l}\text { Clinical } \\
\text { stage }\end{array}$} & $|-| \mid$ & 22 & 1.50 & $1.00-2.00$ & 0.052 \\
\hline & III-IV & 38 & 1.00 & $1.00-1.75$ & \\
\hline \multirow{2}{*}{ Recurrence } & Absent & 32 & 1.00 & $0.00-1.00$ & $0.039 *$ \\
\hline & Present & 14 & 1.50 & $1.00-2.00$ & \\
\hline \multirow{2}{*}{ Outcome } & Remission & 19 & 1.00 & $1.00-3.00$ & 0.392 \\
\hline & Death & 24 & 1.00 & $1.00-2.75$ & \\
\hline \multirow{2}{*}{$\begin{array}{l}\text { Histological } \\
\text { grade }\end{array}$} & Low-grade & 12 & 1.00 & $1.00-2.00$ & 0.229 \\
\hline & High-grade & 48 & 1.00 & $1.00-2.00$ & \\
\hline \multirow{3}{*}{$\begin{array}{l}\text { Invasion } \\
\text { pattern }\end{array}$} & Bands/strands & 9 & 0.50 & $0.00-1.00$ & 0.222 \\
\hline & $\begin{array}{l}\text { Small groups } \\
(n>15)\end{array}$ & 9 & 1.00 & $0.00-2.00$ & \\
\hline & $\begin{array}{l}\text { Cellular } \\
\text { dissociation } \\
(n<15)\end{array}$ & 42 & 1.00 & $1.00-2.00$ & \\
\hline \multicolumn{6}{|c|}{ Tumor core } \\
\hline \multirow{2}{*}{$\begin{array}{l}\text { Nodal } \\
\text { metastasis }\end{array}$} & Absent & 29 & 1.00 & $0.00-1.00$ & 0.635 \\
\hline & Present & 31 & 0.00 & $0.00-1.00$ & \\
\hline \multirow{2}{*}{$\begin{array}{l}\text { Clinical } \\
\text { stage }\end{array}$} & $|-| \mid$ & 22 & 1.00 & $0.00-1.00$ & 0.201 \\
\hline & III-IV & 38 & 0.50 & $0.00-1.00$ & \\
\hline \multirow{2}{*}{ Recurrence } & Absent & 32 & 0.00 & $0.00-1.00$ & 0.214 \\
\hline & Present & 14 & 1.00 & $1.00-2.25$ & \\
\hline \multirow{2}{*}{ Outcome } & Remission & 19 & 0.00 & $0.00-1.00$ & 0.179 \\
\hline & Death & 24 & 1.00 & $0.00-1.00$ & \\
\hline
\end{tabular}

*Statistically significant.

of malignant cells into adjacent tissues by plasmin activation..$^{2,3}$ In addition, uPA/uPAR interaction stimulates signaling pathways that maintain the mitogenic activity of cancer cells, such as focal adhesion kinase (FAK) and extracellular-signalregulated kinase/mitogen-activated protein kinase (ERK/MAPK). ${ }^{18,19}$ According to Lester et al., ${ }^{20}$ uPAR is also involved in epithelial-mesenchymal transition by activation of ERK, phosphoinositide 3-kinase/ protein kinase $\mathrm{B}$ (PI3K/Akt) and proto-oncogene tyrosine-protein kinase (Src) pathways, under hypoxic conditions.

Previous studies ${ }^{21,22}$ on different tumors found that uPA is overexpressed in advanced tumors with lymph node metastasis and recurrence. Regarding OSCC, Yoshiwaza et al. ${ }^{9}$ observed a higher survival rate in cases with a lower uPA expression. Zhang et al. ${ }^{10}$ reported that uPA was more common in cases of SCCOT with lymph node metastasis and stages III-IV, confirming that UPA appears to play a role in neoplastic progression.

In the present study, no statistical significance was observed between uPA and clinical parameters. Similary, another study ${ }^{23}$ on OSCC revealed no association of this protein with lymph node metastasis or clinical stage. Gershtein et al. ${ }^{23}$ reported that just because no association can be established does not mean that uPA is not associated with carcinogenesis. This is based on their observation of a higher uPA expression in tumor tissue in comparison with normal oral mucosal tissue, suggesting uPA is involved in OSCC. Although no association was established between uPA and clinical parameters, an evident expression of uPA was noticed in most cases of SCCOT, especially at the invasion front, suggesting its participation in this carcinoma.

Regarding histological grade, a significant expression of uPA was observed in high-grade versus low-grade tumors. Furthermore, cases with cellular dissociation $(n<15)$ presented an overexpression of uPA. In OSCC, similar results were reported by Yoshizawa et al., ${ }^{9}$ Nozaki et al., ${ }^{24}$ and Inoue et al. ${ }^{25}$, who showed that uPA is associated with the worst pattern of invasion, characterized by a diffuse distribution of neoplastic cords. Thus, these authors suggested uPA could serve as a biomarker to assess the progression of this neoplasm. Additionally, Nozaki et al. ${ }^{24}$ reported that the association of the invasion pattern with uPA indicates the participation of this protein in the degradation of structures important for tissue maintenance.

According to Costa et al. ${ }^{26}{ }^{26}$ the invasion pattern is a criterion of substantial prognostic value, since it reflects the cohesion between neoplastic cells. Well-differentiated OSCC invades well-defined margins, whereas anaplastic 
tumors invade in small cellular aggregates or as isolated cells, characterizing a more aggressive behavior. Additionally, Manjula et al. ${ }^{27}$ suggest that the invasion pattern is an important component of the histological grade of malignancy when evaluating the risk of lymph node metastasis, and may be a useful approach in treatment planning. Based on our results, we believe that higher uPA expression in cases of high-grade tumors and worst invasion pattern indicate an imperative role in the invasion of neoplastic cells in SCCOT.

In relation to uPAR, some authors observed its overexpression in OSCC, resulting in larger sizes, lymph node metastasis and advanced TNM..$^{25,28}$ Moreover, it was also reported to be associated with poorly differentiated cases. ${ }^{29}$ Although no evidence was found in this study regarding a UPAR relationship with the clinical stage, the clinical outcome or the histological grade of malignancy, our results showed that cases with recurrence had greater immunostaining than those without recurrence, corroborating the studies by Memarzadeh et al. ${ }^{30}$ and Kita et al..$^{31}$, conducted in endometrial and gastric cancer, respectively. This represents an important finding, since it reveals that identification of the more aggressive cases could possibly be made by immunostaining, and shows the involvement of uPAR in the progression of this neoplasm.

A third component of the PAShas also been analyzed in some studies: the plasminogen activator inhibitor (PAI-1 or SERPINE1). ${ }^{11,32}$ Initially, PAI-1 was believed to serve as a regulator, inactivating the $\mathrm{uPA} / \mathrm{uPAR}$ complex when plasmin formation is overwhelmed. Nevertheless, studies have shown poor prognosis, and advanced tumors present high expression of PAI$1{ }^{33}$ As such, this protein appears to interact with other mechanisms that are independent of UPA, such as ECM components, EMT induction and the angiogenesis process. This suggests that PAI- 1 is associated with cell migration and metastasis. ${ }^{2,4}$ The high presence of PAS components (uPA, uPAR and PAI-1) in tumors underscores their relevance in carcinogenesis.

Evaluation of the biomarkers in the tumor area revealed higher expression of UPA and UPAR at the invasion front in relation to the tumor core. This finding indicates that the proteins are expressed differently depending on the intratumoral location, but both express greater activity at the tumor-host interface. To our knowledge, although other studies ${ }^{10,29}$ have observed this event, ours was the first to undertake its evaluation. Our findings corroborate the concept that morphological and functional features at the deep invasion front better elucidate the aggressive behavior of OSCC. These biomarkers are part of a proteolytic system that plays a crucial role in cell invasion and in the degradation of components of the basement membrane and extracellular matrix..$^{29}$ As such, they are mostly present in the deepest region of the tumor. Therefore, the invasion front seems to best reflect the biological behavior of these proteins in SCCOT.

The enhanced expression of uPA/uPAR in solid tumors has made them therapeutic targets mostly focused on down-regulation or the blockade of their interaction. As an antagonist of uPA, the 8-mer capped peptide antagonist (Å) has shown promising results inhibiting metastasis and tumor growth in models of breast cancer. ${ }^{34}$ Phase I and II clinical trials in advanced gynecological cancers found $\AA 6$ to be safe and well tolerated. ${ }^{35,36}$ In head and neck tumors, WX-UK1 (3-amidinophenylalanine-based inhibitor)-a serine protease inhibitor of uPA activity-diminished tumor cell invasion by $50 \%$ in cell lines. ${ }^{37}$ Moreover, a Phase I trial showed that its prodrug, WX-671, was safe and mostly associated with mild and moderate adverse effects. ${ }^{38}$ Combined therapies of $\AA 6$ with cisplatin, ${ }^{39}$ and WX-671 with gemcitabe ${ }^{40}$ have also provided a better treatment response in glioblastoma and pancreatic cancer, respectively. The results underscore the importance of understanding uPA/uPAR mechanisms as a way to study therapeutic targets better and evaluate their clinical value adequately.

The main limitation of this study was the sample size. Since our focus was to examine tumors of only a specific location, our number of study patients was limited. In addition, other exclusion criteria, such as previous history of radiotherapy or chemotherapy, incomplete medical records and insufficient tumor tissue for histological and immunohistochemical analysis, further reduced the number of cases. On the other hand, we were able to obtain relevant information regarding SCCOT by the end of the sample selection. 


\section{Conclusions}

Both UPA and UPAR appear to regulate tumor invasion, and are involved in the progression of SCCOT toward a poor prognosis. In general, the high expression

\section{References}

1. Ulisse S, Baldini E, Sorrenti S, D'Armiento M. The urokinase plasminogen activator system: a target for anti-cancer therapy. Curr Cancer Drug Targets. 2009 Feb;9(1):32-71. https://doi.org/10.2174/156800909787314002

2. Pavón MA, Arroyo-Solera I, Céspedes MV, Casanova I, León X, Mangues R. uPA/UPAR and SERPINE1 in head and neck cancer: role in tumor resistance, metastasis, prognosis and therapy. Oncotarget. 2016 Aug;7(35):57351-66. https://doi.org/10.18632/oncotarget.10344

3. Zoppo GJ. Plasminogen activators in ischemic stroke: introduction. Stroke. 2010 Oct;41(10 Suppl):S39-41. https://doi.org/10.1161/STROKEAHA.110.595769

4. Kwaan HC, Mazar AP, McMahon BJ. The apparent UPA/PAI-1 paradox in cancer: more than meets the eye. Semin Thromb Hemost. 2013 Jun;39(4):382-91. https://doi.org/10.1055/s-0033-1338127

5. Anwar S, Yanai T, Sakai H. Immunohistochemical Detection of Urokinase Plasminogen Activator and Urokinase Plasminogen Activator Receptor in Canine Vascular Endothelial Tumours. J Comp Pathol. 2015 Nov;153(4):278-82. https://doi.org/10.1016/j.jcpa.2015.07.003

6. Mekkawy AH, Pourgholami MH, Morris DL. Involvement of urokinase-type plasminogen activator system in cancer: an overview. Med Res Rev. 2014 Sep;34(5):918-56. https://doi.org/10.1002/med.21308

7. Laerum OD, Ovrebo K, Skarstein A, Christensen IJ, AlpízarAlpízar W, Helgeland $L$ et al. Prognosis in adenocarcinomas of lower oesophagus, gastro-oesophageal junction and cardia evaluated by uPAR-immunohistochemistry. Int J Cancer. 2012 Aug;131(3):558-69. https://doi.org/10.1002/ijc.26382

8. Boonstra MC, Verbeek FP, Mazar AP, Prevoo HA, Kuppen PJ, Velde $\mathrm{CJ}$ et al. Expression of UPAR in tumor-associated stromal cells is associated with colorectal cancer patient prognosis: a TMA study. BMC Cancer. 2014 Apr;14(1):269. https://doi.org/10.1186/1471-2407-14-269

9. Yoshizawa K, Nozaki S, Kitahara H, Kato K, Noguchi N, Kawashiri $S$ et al. Expression of urokinase-type plasminogen activator/urokinase-type plasminogen activator receptor and maspin in oral squamous cell carcinoma: association with mode of invasion and clinicopathological factors. Oncol Rep. 2011 Dec;26(6):1555-60. of uPA observed in high-grade tumors and in the worst pattern of invasion, and the high expression of uPAR in cases with locoregional recurrence, suggest that these markers are involved in the aggressiveness of SCCOT, and act mainly at the tumor-host interface.

10. Zhang Z, Pan J, Li L, Wang Z, Xiao W, Li N. Survey of risk factors contributed to lymphatic metastasis in patients with oral tongue cancer by immunohistochemistry. J Oral Pathol Med. 2011 Feb;40(2):127-34. https://doi.org/10.1111/j.1600-0714.2010.00953.x

11. Magnussen S, Rikardsen OG, Hadler-Olsen E, Uhlin-Hansen L, Steigen SE, Svineng G. Urokinase plasminogen activator receptor (UPAR) and plasminogen activator inhibitor-1 (PAI-1) are potential predictive biomarkers in early stage oral squamous cell carcinomas (OSCC). PLoS One. 2014 Jul;9(7):e101895. https://doi.org/10.1371/journal.pone.0101895

12. Warnakulasuriya S. Global epidemiology of oral and oropharyngeal cancer. Oral Oncol. 2009 Apr-May;45(4-5):309-16. https://doi.org/10.1016/i.oraloncology.2008.06.002

13. McCullough MJ, Prasad G, Farah CS. Oral mucosal malignancy and potentially malignant lesions: an update on the epidemiology, risk factors, diagnosis and management. Aust Dent J. 2010 Jun;55 Suppl 1:61-5. https://doi.org/10.1111/j.1834-7819.2010.01200.x

14. Bello IO, Soini Y, Salo T. Prognostic evaluation of oral tongue cancer: means, markers and perspectives (I). Oral Oncol. 2010 Sep;46(9):630-5. https://doi.org/10.1016/j.oraloncology.2010.06.006

15. Rodrigues PC, Miguel MC, Bagordakis E, Fonseca FP, Aquino $\mathrm{SN}$, Santos-Silva AR et al. Clinicopathological prognostic factors of oral tongue squamous cell carcinoma: a retrospective study of 202 cases. Int J Oral Maxillofac Surg. 2014 Jul;43(7):795-801. https://doi.org/10.1016/i.ijom.2014.01.014

16. Bryne $M$. Is the invasive front of an oral carcinoma the most important area for prognostication? Oral Dis. 1998 Jun;4(2):707. https://doi.org/10.1111/j.1601-0825.1998.tb00260.x

17. Silveira EJ, Godoy GP, Lins RD, Arruda ML, Ramos CC, Freitas RA et al. Correlation of clinical, histological, and cytokeratin profiles of squamous cell carcinoma of the oral tongue with prognosis. Int J Surg Pathol. 2007 Oct;15(4):376-83. https://doi.org/10.1177/1066896907304992

18. Monaghan-Benson E, McKeown-Longo PJ. Urokinasetype plasminogen activator receptor regulates a novel pathway of fibronectin matrix assembly requiring Srcdependent transactivation of epidermal growth factor receptor. J Biol Chem. 2006 Apr;281(14):9450-9. https://doi.org/10.1074/jbc.M501901200 
19. Randle DD, Clarke S, Henderson V, Odero-Marah VA. Snail mediates invasion through uPA/uPAR and the MAPK signaling pathway in prostate cancer cells. Oncol Lett. 2013 Dec;6(6):1767-73. https://doi.org/10.3892/ol.2013.1635

20. Lester RD, Jo M, Montel V, Takimoto S, Gonias SL. uPAR induces epithelial-mesenchymal transition in hypoxic breast cancer cells. J Cell Biol. 2007 Jul;178(3):425-36. https://doi.org/10.1083/jcb.200701092

21. Liu Y, Lin D, Xiao T, Ma Y, Hu Z, Zheng $\mathrm{H}$ et al. An immunohistochemical analysis-based decision tree model for estimating the risk of lymphatic metastasis in pNO squamous cell carcinomas of the lung. Histopathology. 2011 Nov;59(5):882-91. https://doi.org/10.1111/j.1365-2559.2011.04013.x

22. Herceg GH, Herceg D, Kralik M, Kulic A, Bence-Zigman Z, Tomic$\mathrm{Brzac} \mathrm{H}$ et al. Urokinase plasminogen activator and its inhibitor type-1 as prognostic factors in differentiated thyroid carcinoma patients. Otolaryngol Head Neck Surg. 2013 Oct;149(4):533-40. https://doi.org/10.1177/0194599813496374

23. Gershtein ES, Batsev AF, Matyakin EG, Kushlinskii NE. Urokinase and tissue plasminogen activators and their PAI-1 inhibitor in tumors of patients with oral mucosal cancer: relationship with the main clinical morphological factors. Bull Exp Biol Med. 2010 Sep;149(3):347-50. https://doi.org/10.1007/s10517-010-0943-y

24. Nozaki S, Endo Y, Kawashiri S, Nakagawa K, Yamamoto E, Yonemura $Y$ et al. Immunohistochemical localization of a urokinase-type plasminogen activator system in squamous cell carcinoma of the oral cavity: association with mode of invasion and lymph node metastasis. Oral Oncol. 1998 Jan;34(1):5862. https://doi.org/10.1016/S1368-8375(97)00028-6

25. Inoue Y, Sugiura T, Matsuki R, Ishii K, Seki K, Shirasuna K. Expression of urokinase-type plasminogen activator (UPA), UPA receptor, and plasminogen activator inhibitor-1 in oral squamous cell carcinoma. Oral Sci Int. 2007;4(1):38-44. https://doi.org/10.1016/S1348-8643(07)80010-3

26. Costa ALL, Araújo Júnior RF, Ramos CCF. Correlation between TNM classification and malignancy histological feature of oral squamous cell carcinoma. Rev Bras Otorrinolaringol (Engl Ed). 2005;71(2):181-7. https://doi.org/10.1016/S1808-8694(15)31308-2

27. Manjula BV, Augustine S, Selvam S, Mohan AM. Prognostic and predictive factors in gingivo buccal complex squamous cell carcinoma: role of tumor budding and pattern of invasion. Indian J Otolaryngol Head Neck Surg. 2015 Mar;67(S1 Suppl 1):98-104. https://doi.org/10.1007/s12070-014-0787-2

28. Christensen A, Kiss K, Lelkaitis G, Juhl K, Persson M, Charabi $B W$ et al. Urokinase-type plasminogen activator receptor (UPAR), tissue factor (TF) and epidermal growth factor receptor (EGFR): tumor expression patterns and prognostic value in oral cancer. BMC Cancer. 2017 Aug;17(1):572. https://doi.org/10.1186/s12885-017-3563-3

29. Bacchiocchi R, Rubini C, Pierpaoli E, Borghetti G, Procacci $P$, Nocini PF et al. Prognostic value analysis of urokinasetype plasminogen activator receptor in oral squamous cell carcinoma: an immunohistochemical study. BMC Cancer. 2008 Aug;8(1):220. https://doi.org/10.1186/1471-2407-8-220
30. Memarzadeh S, Kozak KR, Chang L, Natarajan S, Shintaku $\mathrm{P}$, Reddy ST et al. Urokinase plasminogen activator receptor: prognostic biomarker for endometrial cancer. Proc Natl Acad Sci USA. 2002 Aug;99(16):10647-52. https://doi.org/10.1073/pnas.152127499

31. Kita Y, Fukagawa T, Mimori K, Kosaka Y, Ishikawa K, Aikou T et al. Expression of UPAR mRNA in peripheral blood is a favourite marker for metastasis in gastric cancer cases. Br J Cancer. 2009 Jan;100(1):153-9. https://doi.org/10.1038/sj.bjc.6604806

32. Baker EA, Leaper DJ, Hayter JP, Dickenson AJ. Plasminogen activator system in oral squamous cell carcinoma. $\mathrm{Br} \mathrm{J}$ Oral Maxillofac Surg. 2007 Dec;45(8):623-7. https://doi. org/10.1016/i.bjoms.2007.04.021

33. Duffy MJ, McGowan PM, Gallagher WM. Cancer invasion and metastasis: changing views. J Pathol. 2008 Feb;214(3):283-93. https://doi.org/10.1002/path.2282

34. Guo Y, Higazi AA, Arakelian A, Sachais BS, Cines D, Goldfarb RH et al. A peptide derived from the nonreceptor binding region of urokinase plasminogen activator (UPA) inhibits tumor progression and angiogenesis and induces tumor cell death in vivo. FASEB J. 2000 Jul;14(10):1400-10. https://doi.org/10.1096/fasebj.14.10.1400

35. Berkenblit A, Matulonis UA, Kroener JF, Dezube BJ, Lam GN, Cuasay LC et al. A6, a urokinase plasminogen activator (UPA)derived peptide in patients with advanced gynecologic cancer: a phase I trial. Gynecol Oncol. 2005 Oct;99(1):50-7. https:// doi.org/10.1016/i.ygyno.2005.05.023

36. Ghamande SA, Silverman MH, Huh W, Behbakht K, Ball G, Cuasay $L$ et al. A phase 2, randomized, double-blind, placebocontrolled trial of clinical activity and safety of subcutaneous A6 in women with asymptomatic CA125 progression after first-line chemotherapy of epithelial ovarian cancer. Gynecol Oncol. 2008 Oct;111(1):89-94. https://doi.org/10.1016/i.ygyno.2008.06.028

37. Ertongur S, Lang S, Mack B, Wosikowski K, Muehlenweg B, Gires $O$. Inhibition of the invasion capacity of carcinoma cells by WX-UK1, a novel synthetic inhibitor of the urokinasetype plasminogen activator system. Int J Cancer. 2004 Jul;110(6):815-24. https://doi.org/10.1002/ijc.20192

38. Meyer JE, Brocks C, Graefe H, Mala C, Thäns N, Bürgle M et al. The Oral Serine Protease Inhibitor WX-671 - First Experience in Patients with Advanced Head and Neck Carcinoma. Breast Care (Basel). 2008;3(2 s2):20-4. https://doi.org/10.1159/000151736

39. Mishima K, Mazar AP, Gown A, Skelly M, Ji XD, Wang XD et al. A peptide derived from the non-receptor-binding region of urokinase plasminogen activator inhibits glioblastoma growth and angiogenesis in vivo in combination with cisplatin. Proc Natl Acad Sci USA. 2000 Jul;97(15):8484-9. https://doi.org/10.1073/pnas.150239497

40. Heinemann V, Ebert MP, Laubender RP, Bevan P, Mala C, Boeck S. Phase II randomised proof-of-concept study of the urokinase inhibitor upamostat (WX-671) in combination with gemcitabine compared with gemcitabine alone in patients with non-resectable, locally advanced pancreatic cancer. $\mathrm{Br} J$ Cancer. 2013 Mar;108(4):766-70. https://doi.org/10.1038/bjc.2013.62 